Article

\title{
Status of and Perspectives on River Restoration in Europe: 310,000 Euros per Hectare of Restored River
}

\author{
Ewelina Szałkiewicz ${ }^{1}$, Szymon Jusik ${ }^{2}$ and Mateusz Grygoruk ${ }^{3, *}$ \\ 1 Department of Hydraulic and Sanitary Engineering, Poznań University of Life Sciences, \\ ul. Wojska Polskiego 28, 60-637 Poznań, Poland; ewelszal@up.poznan.pl \\ 2 Department of Ecology and Environmental Protection, Poznań University of Life Sciences, \\ ul. Wojska Polskiego 28, 60-637 Poznań, Poland; jusz@up.poznan.pl \\ 3 Department of Hydraulic Engineering, Faculty of Civil and Environmental Engineering, Warsaw University \\ of Life Sciences-SGGW, ul. Nowoursynowska 166, 02-787 Warsaw, Poland \\ * Correspondence: m.grygoruk@levis.sggw.pl; Tel.: +48-22-593-53-09
}

Received: 5 December 2017; Accepted: 4 January 2018; Published: 8 January 2018

\begin{abstract}
The purpose of the present research was to analyze the available data on river restoration projects in Europe. As the framework of our study, we conducted a structured international survey. We asked selected entities and experts from among those responsible for river restoration in European countries about the details and costs of European Union river restoration projects. We examined 119 river restoration projects that were implemented in Europe between 1989 and 2016; during the collection of data, some of the projects were still ongoing. Based upon the collected data we observed that the number of river restoration projects has been increasing since 1989, which expresses society's growing interest in improving the quality of aquatic environments. We revealed that $56 \%$ of these European river restoration projects have been implemented by dedicated entities and stakeholders, not as part of any structured, larger-scale river restoration policy. This indicates that most European countries do not have integrated plans for river restoration. Our analysis showed that $52 \%$ of the projects analyzed have been designed and implemented without the participation of local stakeholders. It also showed that the budgets for river restoration projects did not differ significantly across various time horizons from 1989 to 2016. In our study, the average cost of restoring 1 ha of an European river was 310,000 euros (EUR). Considering these projects' permanent assets and including their amortization, we calculated the average unit price of a river restoration's value in terms of ecosystem meta-service to be 7757 EUR $\cdot$ ha $^{-1} \cdot$ year $^{-1}$.
\end{abstract}

Keywords: river; restoration; ecosystem; management; Water Framework Directive; ecosystem services

\section{Introduction}

The development of societies is expressed through increasing indices for growth, the level of education and communication efficiency, as well as through a growing demand for a high-quality surrounding environment. Many suspect the latter to be the main driver of environmental restoration [1-3]. Some even deem the classic approaches such as process- and species-based conservation paradigms to lack resilience on a long time horizon, arguing that environmental restoration is the only way to reach sustainability goals [4]. As Suding stated, this situation and the increasing priorities on environmental issues provide exponentially more opportunities for the improvement of environmental quality and sustainable development than at any time before [1].

As synergies in environmental restoration result in measurable economic gains that follow restoration-induced improvements of ecosystems' statuses [5-7], one may suspect that the scientific and political implementation consortia that are restoring various ecosystems worldwide are finally able to provide comprehensive ecosystem restoration and to positively stimulate local economies and societies. 
However, the societal demand for high-quality environments remains spatially heterogeneous, as does the growth in environmental consciousness, education and emotions regarding nature [8-10]. That is why there are specific groups of interest, including people with various objectives and profiles who are responsible for the design and implementation of environmental restoration projects [11].

Unlike for other ecosystems, the restoration of rivers and wetlands remains a global issue [12-14]. These azonal ecosystems occur in every latitude of every continent. The problems related to riverine environments-including modifications in hydromorphology, flow regime, and both longitudinal (upstream-downstream), lateral (channel-floodplain lakes) and vertical (river-hyporheic zone-groundwater) connectivity-remain unrelated to climatic zones and thus are cited and reported on a universal basis [15]. The restoration of rivers and riparian wetlands still has great economic potential; the ecosystem services that these mesobiomes provide have been estimated to retain high economic value [16]. When well-planned, -designed and -managed, restored river and wetlands systems can mitigate the negative consequences of changing land uses and of climate extremes such as floods and droughts, and can also help to sustain biodiversity [17-21]. The restoration of these systems is even more critical due to the fact that, among the ecosystems that Costanza et al. [22] evaluated, only two had decreasing economic unit values for the services they provide, namely, freshwater wetlands and estuaries, both of which are related to-and are dependent on-rivers and their valleys maintaining good status. Moreover, Costanza et al. also reported that the area of these ecosystems is decreasing on a global scale. Hence, the restoration of rivers and related riparian ecosystems is observed to become an element of (inter)national strategy that starts to be included in water policies.

In the European Union (EU), the Water Framework Directive (WFD) [23] has regulated actions related to rivers and their ecosystems since 2000. This regulation promotes integrated water management. One of the WFD's meta-goal is to achieve rivers' good ecological status or at least, for heavily modified cases, achieve their good ecological potential. As riverine systems face existing pressures and most are in a deteriorating state, large-scale river restoration strategies seem to be the ultimate measure for fulfilling the WFD's requirements, the goals of other environmental regulations as well as sustainable development [24,25]. Therefore, especially from the EU's perspective, the revision and general assessment of past and present river restoration projects-which so far has not been done-would (1) provide important information about these projects' costs, results and future prospects, and (2) help determine whether contemporary river restoration tends to involve strategic action or be reduced to the costly hobby of certain groups of stakeholders.

Our paper addresses the following research goals: (1) to quantify and assess the scale of particular river restoration projects in the EU; (2) to identify whether the reviewed river restoration projects remain individual, spontaneous actions, or if they are now elements of more widely planned river restoration strategies; (3) to reveal the scale and share of EU and national funding spent on river restoration; and (4) to assess the approximate average cost of river restoration, as this reveals the value that societies are willing to pay to maintain healthy rivers.

\section{Materials and Methods}

Our study was based on a questionnaire (Table 1) that contained both open- and closed-ended questions. The open-ended queries focused on basic information (river, country, project's start year and completion year), as well as on more detailed information such as budget and share of funding (if any) from the EU. If the budget for a given restoration project was not known or if the respondent did not wish to provide a detailed budget, he or she could select from ranges of costs. The close-ended questions concerned specific (mainly technical and administrative) issues of particular projects, namely the spatial scale of the project, technical solutions applied, the level of local communities' participation (if any), monitoring of project results and information regarding whether the project was part of a large-scale strategy or plan. The questionnaire was distributed to more than 300 European specialists involved in the implementation of or research on restoration of rivers and riparian ecosystems. The specialists 
were found on the basis of projects contained in the River Wiki [26] database and also in the network of river restoration organizations (including the European Centre for River Restoration, ECRR).

Table 1. Closed-ended questions asked in the questionnaire.

\begin{tabular}{lll}
\hline \multicolumn{1}{c}{ Question } & \multicolumn{1}{c}{ Answers } \\
\hline & a. & nationwide authorities \\
Entity responsible for the project * & b. & provincial/regional authorities \\
& c. & non-governmental organization (NGO) \\
& d. & private investors \\
& e. & \\
\hline
\end{tabular}

$\begin{array}{lll} & \text { a. } & \text { works within channel } \\ \text { Target of the project * } & \text { b. works within floodplain } \\ \text { c. works within catchment }\end{array}$

\begin{tabular}{lll}
\hline a. & river reach length $<2 \mathrm{~km}$ \\
Spatial scale of the project & b. & river reach length $>2 \mathrm{~km}$ \\
& c. & whole river \\
d. & more than one watercourse \\
\hline
\end{tabular}

\begin{tabular}{|c|c|c|}
\hline Solutions which were used * & $\begin{array}{l}\text { a. } \\
\text { b. } \\
\text { c. } \\
\text { d. } \\
\text { e. } \\
\text { f. } \\
\text { g. } \\
\text { h. } \\
\text { i. }\end{array}$ & $\begin{array}{l}\text { removal of hydrotechnic structures } \\
\text { introduction of deflectors } \\
\text { introduction of logs or other wood elements } \\
\text { biological strengthening of the banks } \\
\text { creation of spawning grounds } \\
\text { construction of fish ladders } \\
\text { crosscut of the channel or other diggings } \\
\text { introduction of macrophytes } \\
\text { others }\end{array}$ \\
\hline Source of the project funding * & $\begin{array}{l}\text { a. } \\
\text { b. } \\
\text { c. } \\
\text { d. } \\
\text { e. }\end{array}$ & $\begin{array}{l}\text { government budget } \\
\text { EU funding } \\
\text { association or foundation funds } \\
\text { private funds } \\
\text { others }\end{array}$ \\
\hline $\begin{array}{l}\text { Did the local community participate in the } \\
\text { project? }\end{array}$ & & Yes/No \\
\hline $\begin{array}{l}\text { Have the monitoring of the restoration project } \\
\text { been performed? }\end{array}$ & & Yes/No \\
\hline $\begin{array}{l}\text { Was the project a part of a larger restoration } \\
\text { plan (national, international)? }\end{array}$ & & Yes/No \\
\hline
\end{tabular}

* Questions with possibility to choose multiple answers.

The general analysis of the questionnaire consisted of summing up the number of projects and answers for each query. The projects were collated by the year when they were finished. The earliest project for which we have data is from 1989. The most recent year we considered was 2016, but some of the projects were still running and the end of that year. However, to keep the analysis clear, we assumed that, in such cases, 2016 was the terminal year for these restoration projects.

In the next step, we analyzed the setup of the river restoration projects. We attempted to determine whether these projects analyzed were planned and implemented with any active participation of 
the local authorities and communities; whether their results were monitored to allow for adaptive management and to state whether the restoration reached assumed goals; and whether the river restoration initiatives belonged to or result from any structured, large-scale river restoration strategy (e.g., a national river restoration plan). Subsequently, the spatial scale of the projects was analyzed. The answers were divided at restoration measures in: river channel, floodplain, whole catchment and complex projects including catchment-scale measures and presented according to year of completion. Additionally, information about entity responsible for the project was presented correspondingly to number of projects in each group: National, Regional, NGO's, NGO's + National, and other. Finally, the proportion of source of funding was examined. Processed results of the survey were subjected to statistical analyses and the parametric $t$-test was applied to reveal statistical differences of analyzed variables. Differences analyzed were considered significant if the $\mathrm{p}$ values of the test were lower than 0.05 .

The collected structured data allowed for calculations of the unit cost for river restoration project in Europe, expressed in kEUR (thousands of euros)/ha. Data on project costs and sizes of rivers restored (average width and total length of the restored stretch) were used in these calculation. Although this information provides only a very general approximation, we found it critical, as it is the most accurate economic measure of a river's aggregated ecosystem services. This cost refers to the amount of funds that stakeholders will pay to bring back a functioning riverine ecosystem that provides aesthetic value as well as services such as biodiversity, self-purification, and sustainable flood/drought mitigation.

\section{Results}

We obtained 105 questionnaire responses from 19 countries, of which 102 were valid sources of data for the analysis. The remaining three responses did not contain sufficient data for the analysis planned in the framework of our study. This is response rate of $36 \%$, which we considered sufficient for purposes of our study. Altogether, we analyzed 119 river restoration projects in detail (Figure 1). The collected information about these projects is provided in the Supplementary Material. Among the projects analyzed there were 56 projects from Western Europe (Austria, Belgium, Luxembourg, France, Germany, The Netherlands, Ireland, Spain and UK), 41 projects from Central and Southern Europe (Croatia, Hungary, Italy, Poland, Romania and Slovenia) and 23 projects from Northern Europe (Denmark, Estonia, Sweden and Finland).

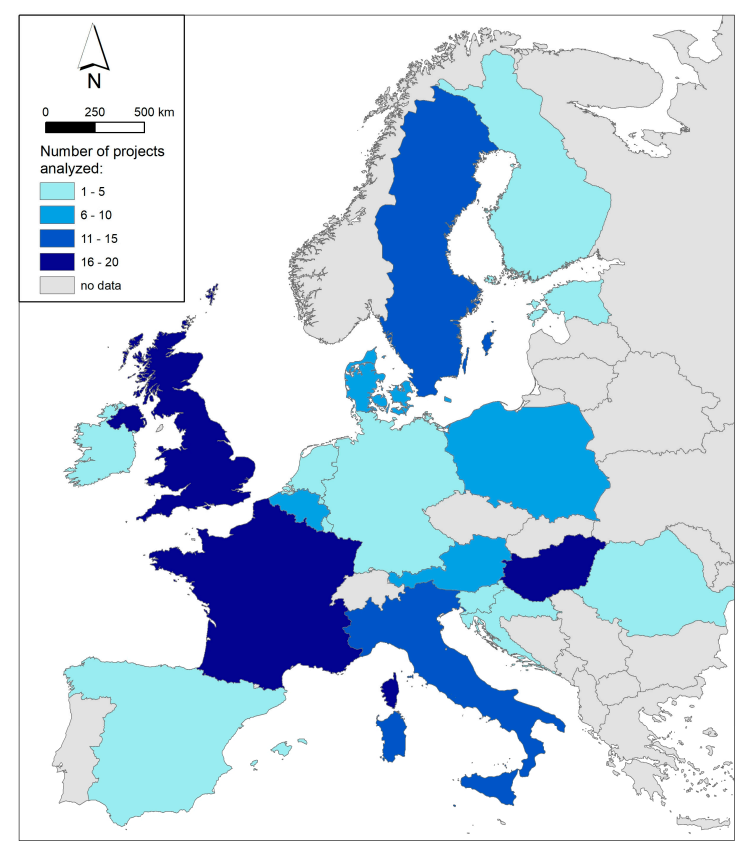

Figure 1. Number of river restoration projects collected from each country. 
We are aware that other European countries have implemented river restoration projects that we did not account for [26-31] having no responses containing information required for our analyses. We are also aware that in countries we got responses from there have been other river restoration projects completed (e.g., [26-28]) that we did not address in our analysis having no information, for example, on project budgets. However, collected data from 119 projects that have been well distributed in Europe we considered a reliable sample for the analysis.

The number of European river restoration projects in the countries for which we have data has clearly increased since the last two decades of the 20th century (Figure 2). Less than a half of the projects included the active participation of local communities (Figure 3A). Approximately $80 \%$ of initiatives included the monitoring of project efficiency (Figure 3B). Surprisingly, only approximately $44 \%$ of the projects were part of large-scale (e.g., nationwide) river restoration policies, meaning that the majority of the EU river restoration projects comprised the individually planned actions of interested entities (Figure 3C).

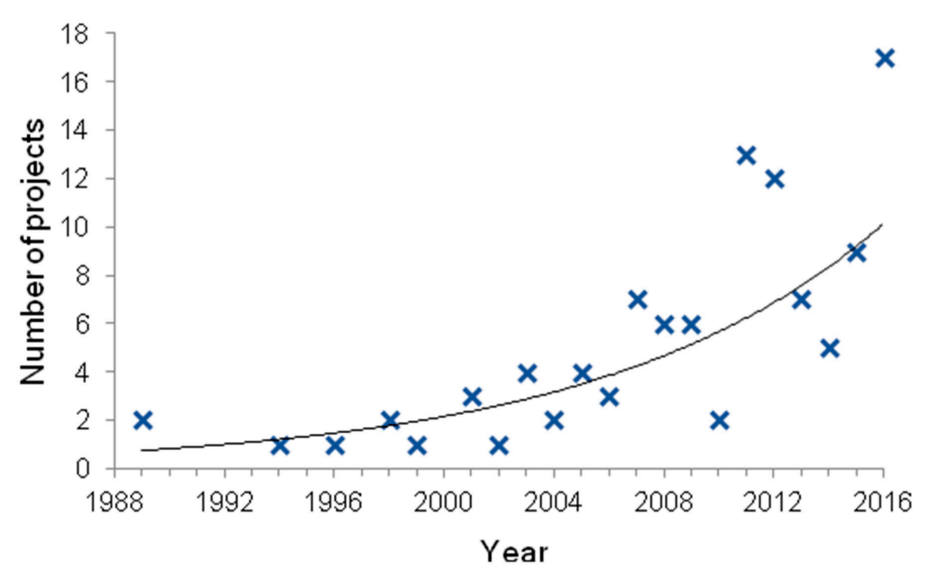

Figure 2. Number of river restoration projects finalized each year (1989-2016).
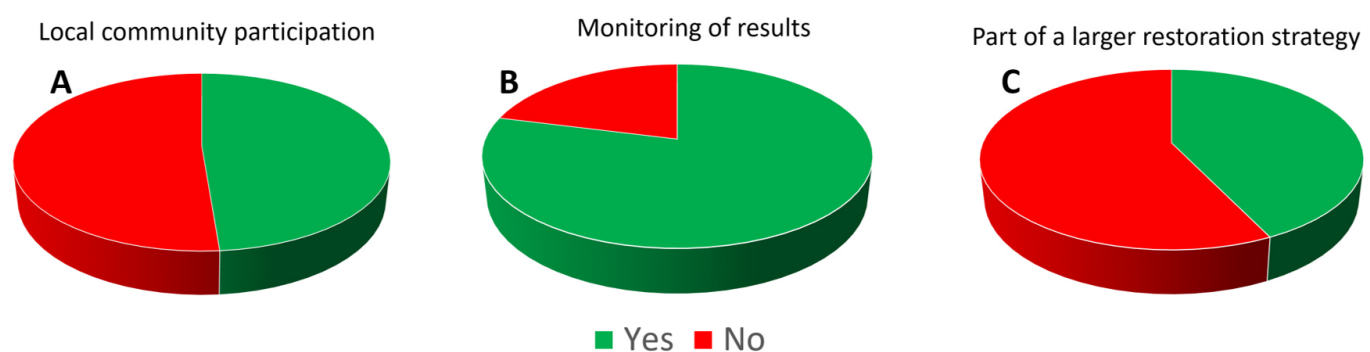

Figure 3. Proportion of the projects analyzed with participation of local communities in project design/implementation (A), share of the projects which results were methodologically monitored (B) and projects that remained a part of a larger (e.g., country-wide) river restoration strategy (C).

Regarding the main goals of the river restoration projects, we revealed that an increasing number of projects are oriented beyond the river channel (to include the floodplain and the whole catchment; Figure 4). By time frame, the most comprehensive and abundant projects, including actions in the river channel, floodplain and catchment (or a mixture of these measures), occurred in 2016, the most recent time period (Figure 4). This indicates that river restoration managers account for systematic solutions and address ecohydrological process at the catchment scale. The projects in the oldest time frame considered (1989-2000) did not include any actions oriented toward catchment-scale processes and instead concentrated mainly on the river itself, although a few floodplain-related measures were implemented (Figure 4). 


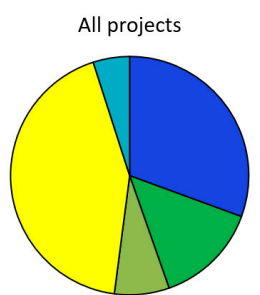

2006-2010

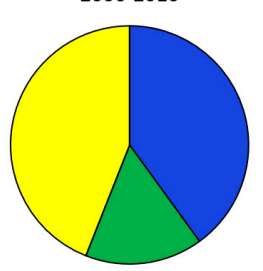

$\square$ Channel

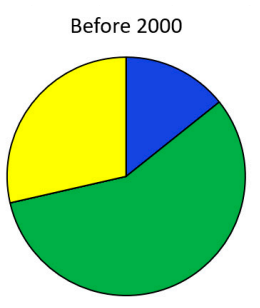

2011-2015

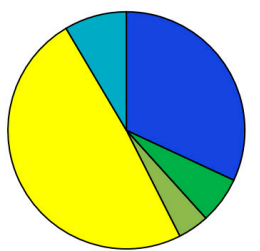

$\square$ Channel \& Floodplain

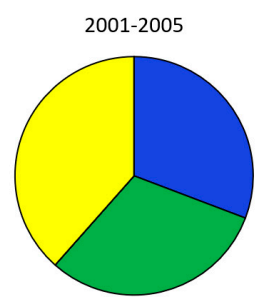

After 2016

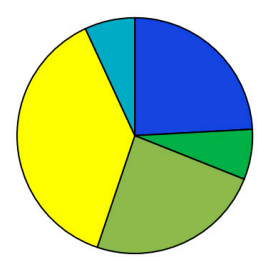

口Channel, Floodplain \& Catchment

Figure 4. Proportion of the projects in selected time frames oriented at restoration measures in river channel, floodplain, whole catchment and complex projects including catchment-scale measures.

Among the river restoration projects analyzed, the majority (51\%) were designed and implemented by regional authorities or by other entities working on a regional scale (Figure 5A,B). Nongovernmental organizations (NGOs) were reported to have implemented $13 \%$ of the projects ( $7 \%$ in partnerships with national-scale institutions such as National Environmental Directorates and $6 \%$ run by NGOs on their own). The remaining projects were run by either national-scale entities or by other consortia ( $19 \%$ and $18 \%$, respectively; Figure $5 \mathrm{~B}$ ).
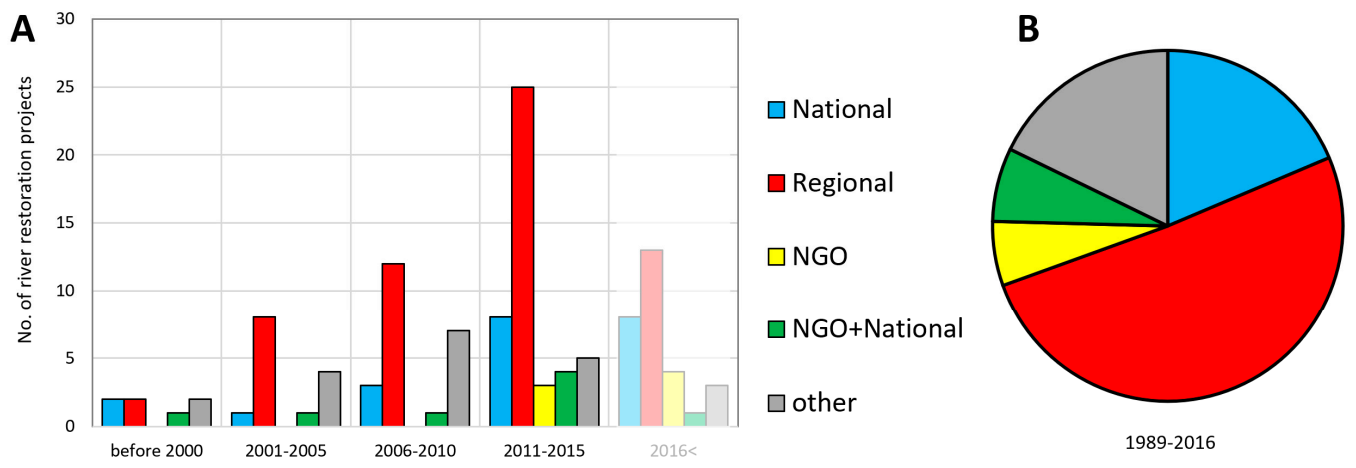

Figure 5. Types of entities responsible for the implementation of particular river restoration projects in particular time frames analyzed (A), and general portion of the each entity in the analyzed period (B). The last time frame is shielded as it is still running and the results present only partial view.

When analyzing the survey results, we observed that the numbers of projects designed and implemented by regional-scale authorities increased significantly from 1989 to 2015 (Figure 5A). The number of NGOs and national consortia implementing river restoration projects did not increase in that time. No project run solely by NGOs were present before 2011 (Figure 5), but they started to occur after that year. Because the time frame after 2016 was not fully reported, we do not draw conclusions about which authorities were implementing river restoration projects in this period. However, based upon the results of the survey, we observed that the number of NGO-run projects has increased, even as the number of projects implemented by national- or regional-scale entities remained the same or declined.

Analysis of the funding sources for the river restoration projects revealed that approximately half of initiatives analyzed across all time frames were cofinanced, with the funds originating directly 
from EU subsidies (Figure 6A). 22.2\% of the projects had nongovernmental funding, which proves that associations and groups of enthusiasts, similarly to, for example, the US [11], play an important role in river restoration in Europe. Among the projects in the 1989-2000 period, none were supported by EU funds (Figure 6A).

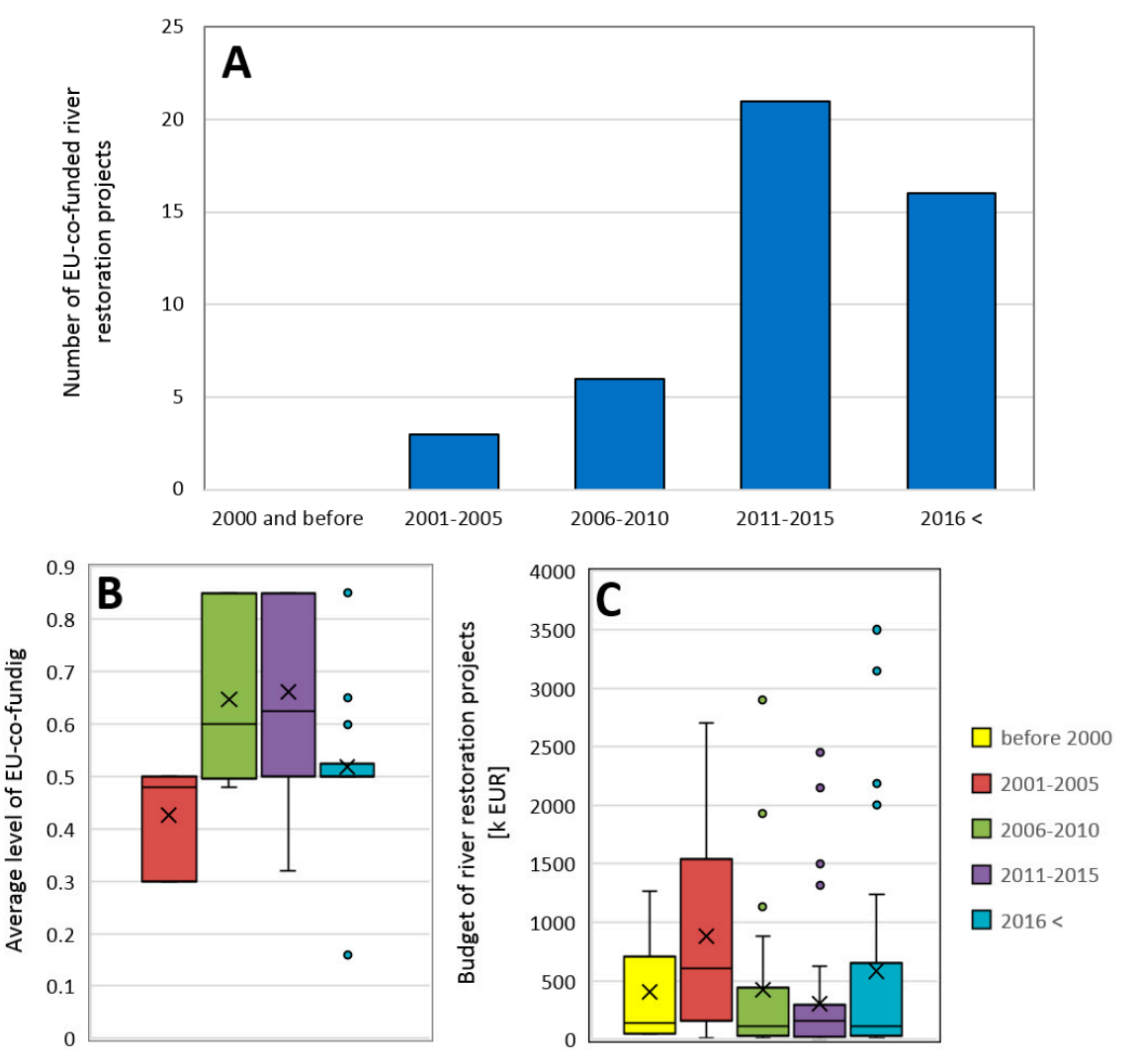

Figure 6. Selected characteristics of river restoration projects analyzed: (A) number of projects co-funded by the EU; (B) average level of EU funding; (C) average cost of river restoration project (kEUR per project). Box-plot charts (B,C): box represents the range from the $25 \%$ to $75 \%, \times$-average value, vertical line in the box-median, whiskers represent maximum and minimum values, dots represent outlying values.

The level of EU co-funding for river restoration projects has increased from an average of $43 \%$ (in 2001-2005) to an average of 65\% (in 2011-2015) (Figure 6B). In the last time frame analyzed (2016 onward), the rate of EU co-funding decreased to $52 \%$. Although the last time frame analyzed is still not complete, as it does not cover a full five-year period, the vast number of restoration projects reported for this year (Figure 1) allows us to derive conclusions on levels of the EU cofounding in these time frame as well. Remaining parts of the projects' budget have been covered by the government budget (which provided the only source of funding for the $39 \%$ of the projects) and other sources. In the years analyzed, the total budgets for river restoration projects did not differ significantly (Figure 6C). The $t$-test showed that there was only a significant difference between two periods, as the projects implemented in 2001-2005 were significantly more costly than those implemented in 2011-2015 (t-test $p$ value was equal 0.028 ). This fact likely presents the quick increase in interest in river restoration after implementing WFD and the fact that river restoration before was not that frequent as in the years later.

Once considering the total budgets of the river restoration projects and the areas of their influence, we calculated these projects' average unit value per hectare of restored river (Figure 7). We revealed that, on average, the cost of restoring 1 ha of river was 310,000 EUR (310 kEUR), with a range from $99 \mathrm{kEUR} / \mathrm{ha}$ (in 2000 and before) to $353 \mathrm{kEUR} / \mathrm{ha}$ (in 2006-2010; Figure 7). After excluding four 
extremely outlying values (two Italian projects on the Draganziolo and Marzenego rivers, with unit restoration costs of 2000 and 4500 kEUR/ha, respectively; and two French projects on the Bievre and Petersbach rivers with unit restoration costs of 2600 and $5680 \mathrm{kEUR} / \mathrm{ha}$, respectively), the average unit restoration cost was only $195 \mathrm{kEUR} /$ ha (Figure 7). We decided to provide the resulting value with- and without consideration of outlying values as (1) we did not have any clues to exclude these values from calculation, but (2) these four outlying values has made the average unit cost of restoration of 1 ha of the river increasing by $59 \%$ comparing to the average unit cost of river restoration calculated with all 119 values considered. Outlying values refer to projects which were addressed at the scale of floodplain and catchment. Under all four projects there were hard engineering earthworks performed, which were aimed to change significantly the flow regime, which may explain significant costs reported within these projects. Additionally, these projects were followed by extensive monitoring. Despite these outlying values, the differences in the unit river restoration costs across the time frames analyzed were not statistically significant ( $t$-test $p$ values were higher than 0.05 ). This observation leads to the conclusion that the unit cost of river restoration, although strongly variable from site to site and highly dependent on the measures applied, remained at a similar average level throughout the period from 1989 to 2016 on the pan-European scale.

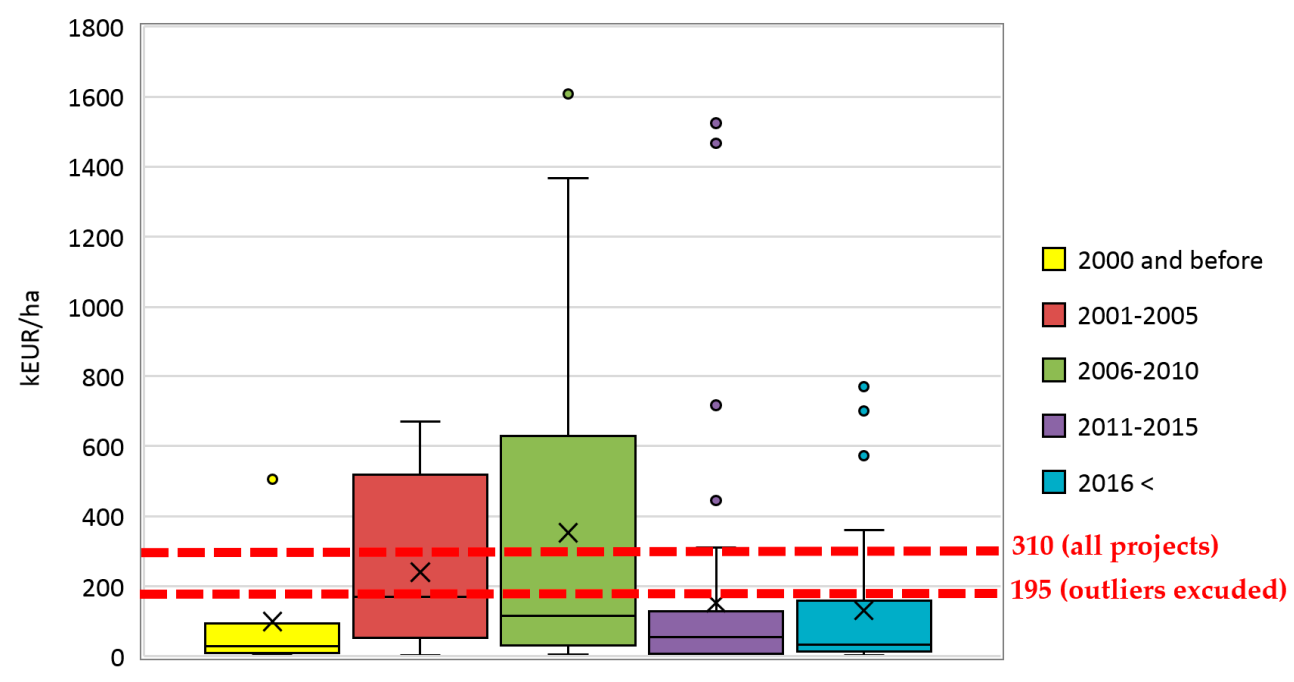

Figure 7. Distributions of unit costs of river restoration projects (kEUR/ha) in selected time frames. Box represents the range from the $25 \%$ to $75 \%, \times$-average value, vertical line in the box-median, whiskers represent maximum and minimum values, dots represent outlying values. kEUR stands for a thousand of Euro.

Analyzing the unit costs of river restoration projects with respect to their spatial scales (catchment; channel; floodplain; channel and floodplain together; or channel, floodplain and catchment together; again, excluding the four outlying Italian and French restoration projects), we found that the differences among these groups were more significant than those between the time frames (Figure 8). The significant differences obtained for pairs; channel-catchment, floodplain—catchment, channel and floodplain—catchment and channel and catchment and floodplain — channel and floodplain ( $t$-test, at the level of significance 0.05 ).

In general, the unit costs of the catchment-scale river restoration projects (average: $32 \mathrm{kEUR} / \mathrm{ha}$ ) were significantly lower than for other types of projects. The highest statistical significance was recorded for the difference between the catchment-scale projects and the joint channel- and floodplain-oriented actions (average: $280 \mathrm{kEUR} / \mathrm{ha}$ ). This observation is based on the types of actions implemented at the catchment-scale projects, which mostly involve planting trees and other low-cost actions (see Supplementary Material). The most expensive actions were implemented in the channel-floodplain and floodplain-only scales, and they included floodplain-lake reconnections 
and dike relocations. As the number of projects varied strongly across the 19 countries (from 1 to 20) making particular countries' projects incomparable, we decided not to differentiate the unit cost of river restoration at the country level.

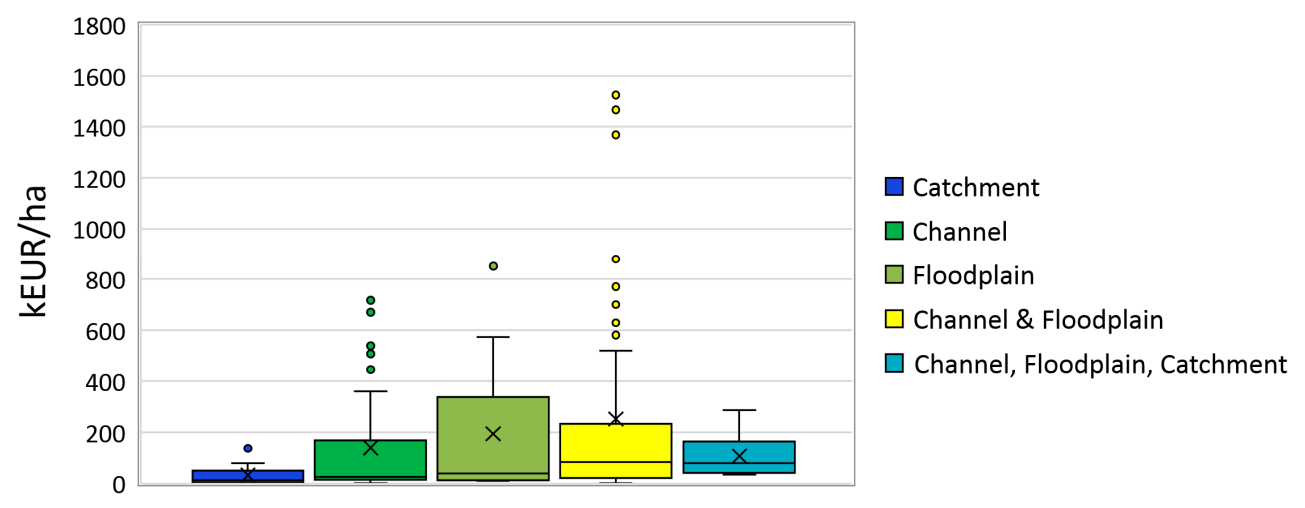

Figure 8. Distribution of unit costs of river restoration projects (kEUR/ha) with respect to different spatial scales. Box represents the range from the $25 \%$ to $75 \%, \times$-average value, vertical line in the box-median, whiskers represent maximum and minimum values, dots represent outlying values. kEUR stands for a thousand of Euro.

\section{Discussion}

First and foremost, we are aware that the analyzed sample covers only a portion of river restoration projects implemented in European countries. For example, the River Wiki [29] and Onema [30] databases that are available in English, contain many more records, showing that of the countries in Europe, only the UK and France have hundreds of river restoration projects [30,31]. However, most of these projects lacked information about river lengths and precise project budgets, which prevented us from considering these data reliable enough for use in our study. Many projects related to the restoration of floodplain environments were also reported; they were oriented mainly at wetlands (e.g., ditch blocking) and, as such, could not be analyzed as river restoration per se. Bearing this issue in mind, however, the results presented in our analysis, which are based on 119 projects from 19 countries, reflected the most relevant, general advances in EU river restoration's progress at the end of the 20th and start of the 21st century.

Our survey results tended to mirror the conclusions provided by Palmer et al. [15] and Wohl et al. [32]. Similarly to these studies, we revealed that the interest in restoring rivers has been increasing in Europe and that river restoration projects become more complex and comprehensive. The sharp increase of the number of projects implemented after the year of 2005 is likely connected to the fact of implementation of WFD that promotes river restoration on a pan-European scale. In our analysis of the structure of river restoration projects, we noted that less than half of all the projects (42\%) were part of a larger restoration strategy. Therefore, the majority of river restoration projects were designed and implemented on a site basis, driven by the river managers' and stakeholders' desire to improve the rivers. On the one hand, this can be considered a good prerequisite for river restoration in the future, as the pattern revealed shows that managers and stakeholders do not need special strategies or plans for their rivers. Their actions in the design and implementation of river restoration projects tend to reflect the growing societal demand for high-quality ecosystems, which Suding [1] foresaw as the main driver for environmental restoration in the 21st century. On the other hand, the lack of the comprehensive river restoration strategies in particular countries could remain an obstacle for certain projects that should be structurally implemented and that should not depend on the fluctuations of societal moods. One might expect that, if the availability of external funds for river restoration projects were to decline (e.g., due to the EU shifting its priorities away from environment and toward agriculture), then the lack of structured, national river restoration plans would inhibit the design of new projects. The number 
of EU-co-funded river restoration projects is increasing, and the cofinancing rate has reached 50-65\% in most countries (or, in some cases, 95\%; Figure 6), which has led to enhanced cooperation between NGOs and regional (or national) official entities (Figure 5). However, without structured strategies and planned cooperation between NGOs and national (or regional) authorities, river restoration projects will likely remain hobbyists' activities rather than comprehensive country-level actions that would produce measurable improvements in degraded rivers' statuses. Even if local projects may have more information concerning the source of the problem and need for restoration more than national scale initiatives, regulations and plans may support feasibility of restoration actions.

Although Wohl et al. [32] reported that most river restoration projects are oriented at one river only and that the measures applied remain limited to a single action (e.g., changing hydromorphology or opening migration barriers), we found this status to be changing. Starting in 2000, we observed an increasing heterogeneity of measures. These measures were formerly limited to the river channel and floodplain, but the set of actions that were undertaken in the most recent time frame had expanded to include the catchment and its integrated actions. The most significant shift in this manner occurred in 2011-2015 and from 2016 onward (Figure 4). The growing scientific interest in river restoration [33] meant that the vast majority (78\%) of projects included structured before-and-after control-impact monitoring. Sadly, less than a half of the projects were designed and implemented with the active participation of local communities (Figure 4). This status frequently led to conflicts between local stakeholders and implementing authorities [34]. Conflicts predominantly arose when the communication process began too late in a project's life or failed to put the restoration project in a local context [35]. A higher level of participation from local communities and other relevant stakeholders has already been determined to have a positive impact on environmental management projects, and a special emphasis on ecological restoration has resulted in more comprehensive measures, longer project life and longer-lasting results $[36,37]$. However, ensuring a high level of stakeholder participation in a restoration project requires targeted communication, and it is efficient only if the gaps related to the science-practice interface have been narrowed [35]. Either way, those who wish to implement successful river restoration projects should foster the wider involvement of stakeholders in the project's design and implementation and in measures that ensure the sustainability of the projects' results.

We estimated the average unit costs for EU river restoration projects, expressed in EUR·ha ${ }^{-1}$, and although we calculated these values with a relatively small sample, there were few statistically significant differences across temporal, spatial or technical scales. The lack of information about some projects' longevity prevented us from defining the direct economic value of the actions in each year, for comparison with the value of the ecosystem services for riparian and riverine ecosystems, as other authors have calculated. Based on the collected answers from the participants, we could not estimate the desirable persistence of the projects' ecological results over a certain duration. Although the goal of a restoration project should be to enhance the existence of resilient river systems, regardless of the duration $[3,9,14,15,32]$, most restoration-related actions are technical interventions (fish-ladder construction, floodplain-lake reconnection, etc.). Hence, these projects could be considered permanent assets that undergo amortization (depreciation over time). The annual depreciation (amortization) rate applied to the calculations made it feasible for us to calculate the annual value of each river restoration per hectare. According to the EU regulations, amortization rates of general permanent assets (e.g., buildings) varies from $1.47 \%$ in Spain up to $12 \%$ in Greece [38]. According to Poland's legal regulations [39], the amortization rate of permanent assets (hydrotechnical constructions, land reclamation or drainage systems, weirs, spillways, etc.) is $2.5 \%$ per annum. This means that permanent assets are designed and constructed to function for 40 years ( 1 year $/ 2.5 \%$ ). This value is close to the average of the EU amortization rates [38] and though it was used in our study to determine the annual average cost of river restoration projects per hectare per annum. The average cost of river restoration projects per hectare per annum would be $7757 \mathrm{EUR} \cdot \mathrm{ha}^{-1} \cdot \mathrm{year}^{-1}\left(310 \mathrm{kEUR} \cdot \mathrm{ha}^{-1} \cdot 40 \mathrm{years}^{-1}\right)$, which is equal to roughly $8920 \mathrm{USD} \cdot \mathrm{ha}^{-1} \cdot \mathrm{year}^{-1}$. Excluding the four outlying values referred to above, the unit costs of river restoration were $4875 \mathrm{EUR} \cdot \mathrm{ha}^{-1} \cdot \mathrm{year}^{-1}\left(5606 \mathrm{USD} \cdot \mathrm{ha}^{-1} \cdot \mathrm{year}^{-1}\right)$. 
These values represent the price that European society wishes to pay (technically, has already paid) to restore the analyzed rivers' functions per year. Hence, we consider this value to be the monetary dimension of healthy rivers' ecosystem meta-service. Due to each river restoration project's complex aims and measures, it is difficult to calculate the elementary values of a particular ecosystem's services (e.g., a restored river as a new habitat for fish), but the given annual unit cost of restoring one hectare of a river system is likely to represent the average long-term value of that river's services.

Interestingly, the calculated unit cost of river restoration may now be referred to as the value of riverine ecosystem meta-service and is similar to the average worldwide unit value of ecosystem services that de Groot et al. calculated for rivers and lakes combined [40] (4247 USD.ha ${ }^{-1} \cdot$ year $^{-1}$; ranging from $1446 \mathrm{USD} \cdot \mathrm{ha}^{-1} \cdot$ year $^{-1}$ to $7757 \mathrm{USD} \cdot \mathrm{ha}^{-1} \cdot \mathrm{year}^{-1}$ ). At the same time, the calculated value is a bit higher than the quantities for some single ecosystem services calculated in individual studies (such as flood retention, as calculated by Grygoruk et al. [21] and priced at approximately 500 EUR.ha ${ }^{-1} \cdot$ year $^{-1}$ or 590 USD.ha ${ }^{-1} \cdot$ year $^{-1}$ ), but lower than the ones calculated by Costanza et al. (11,727 USD.ha ${ }^{-1}$.year ${ }^{-1}$ for calculations published in 1997 [16] and 12,512 USD.ha ${ }^{-1} \cdot$ year $^{-1}$ for calculations published in 2014 [40]). One might suspect that the differences shown above, result from the fact that both de Groot et al. [40] and Costanza et al. [16,22] used different calculation algorithms and also dealt with lakes in addition to rivers. However, the river restoration projects that we analyzed also referred to floodplains, which de Groot et al. [40] and Costanza et al. [16,22] listed in a different category. Ecosystem services of floodplain wetlands in these studies were priced nearly ten times higher than the value we calculated for rivers. Despite these differences, all of the cited values of river ecosystem services have the same order of magnitude. This allows us to hypothesize that the methodology we used to assess the unit value of the riverine ecosystems' meta-service (on the basis of river restoration costs), thus expressing societies' willingness to pay for healthy rivers, is a novel, but reliable approach. One should be aware that the given value representing 'willingness to pay' does not necessarily reflects on the success of particular restoration project. Multiple projects, although well planned, were reported not to fulfill assumed monitoring-based criteria of success [41]. Moreover, rivers to be restored usually provide some services even though their ecological status is poor. Then, the value added to such rivers by restoration remains only a share of the total value of the ecosystem service of these rivers. Moreover, restored rivers usually require some post-restoration adaptive management which also requires additional budget $[14,15,25,27]$. Hence, assuming that (1) restoration goals might not be fully met, (2) rivers before restoration still provide certain measurable services and (3) once the restoration has been completed, river still requires adaptive management, the calculated 7757 EUR $\cdot \mathrm{ha}^{-1}$.year ${ }^{-1}$ should be considered a conservative, minimum-possible value of ecosystem meta-service of average European river.

One should also be aware that every river restoration project is strongly site-specific in terms of the river's characteristics (width, depth and stretch length), the project's spatial scale (channel, floodplain or catchment) and the measures applied (from planting trees to heavy mechanical works in the channel). Moreover, labor and investment costs also were strongly variable across the set of countries analyzed. However, the general lack of statistical significance in the differences between the projects' budgets across the 19 countries and the time frames analyzed, also with respect to the unit costs, allow us to hypothesize that the calculated unit value of river ecosystems' meta-service is a reliable value for the average European river. As such, our results could be carefully applied in EU-scale studies and policies regarding the value of rivers.

Among the projects analyzed, relatively few dam-removal initiatives were reported. Some new initiatives are, however, being planned [42] and implemented [43], mainly in Western European countries; this allows us to suspect that the number of removed dams will increase across the continent. Similarly, observing advances in dam removal around the world, including the best documented dam removals in the US [44], we foresee that the 21st century will include more ecosystem-economy-based discussions; our results, which are oriented at the calculation of healthy rivers' services, may contribute to these discussions. The results of the research on dams' downstream effects provides sufficient 
evidence that dam-reservoir-induced flow-regime changes and the related negative responses of humans and of riverine and riparian ecosystems must be addressed through (costly) mitigation measures [13,45-47].

On the other hand, even though the need for diverse, well-developed and resilient riverine ecosystems has been agreed upon for quite some time [48], in recent discussions, scholars have documented and even-surprisingly-promoted ideas related to hard technical interventions (including the construction of new dams and hydrotechnical infrastructure) as a sine qua non for growth [49]. Muller et al. [49] hypothesized that humanity—for its own sake and benefit—is likely to continue degrading rivers by introducing newly built infrastructure than to restore the rivers' environmental features. However, along with increases in sustainable growth and outstanding recent advances in ecological engineering, with more than 1000 dams removed in the US [44] more than 1 billion USD spent on river restoration in the US [50] and more than 23,000 river stretches restored in Japan [51] the awareness of the need for a high-quality environment will also rise [52,53], so we believe this negative scenario will not come to pass.

\section{Conclusions}

We analyzed 119 river restoration project from $19 \mathrm{EU}$ countries, revealing that the number of river restoration projects has been increasing over the time frame analyzed (1989-2016). We also observed that the complexity of these river restoration projects has increased; in addition to the restoration measures in river channels and floodplains, more catchment-scale initiatives are now being implemented. We also revealed that the majority of river restoration projects were not done in the framework of any larger (e.g., country-scale) policy, meaning that most are individual actions implemented by groups such as regional authorities. We also observed an increasing involvement of NGOs across the time frames. By analyzing the projects implemented in a variety of countries across multiple spatial and temporal scales, we revealed that the unit cost of river restoration does not change significantly across these scales. The average cost of restoring 1 ha of a river system was $310 \mathrm{kEUR}$ (195 kEUR excluding four outlying values) and did not significantly change with respect to the scale of the project, the country of implementation or the measures applied. The EU's average contribution to these projects' budgets has also increased, reached a typical range of 50 to $60 \%$. We concluded that the EU's contributions and the implementation of the WFD significantly increased the number of river restoration projects. It is likely that both increasing environmental concerns about rivers and legal requirements to increase rivers' ecological status (potential) driven by the WFD became important drivers inducing growing interest in river restoration. This hypothesis may be positively verified when observing the level of EU funding for river restoration projects that significantly increased once the WFD have been implemented and, since then, have remained on a similar level, much higher than before the year of 2005 (Figure 6).

On the basis of the obtained data and our subsequent calculations, we estimated the average unit cost of river restoration per hectare to be $7757 \mathrm{EUR} \cdot \mathrm{ha}^{-1} \cdot \mathrm{year}^{-1}\left(8920 \mathrm{USD} \cdot \mathrm{ha}^{-1} \cdot \mathrm{year}^{-1}\right.$ ). We stated that this value reflects society's willingness to pay for a healthy river. Therefore, the calculated value can be referred to as monetary expression of river systems' ecosystem meta-service, encompassing a range of individual services. This measure can be applied to European environmental policy to address the sustainable management of riverine ecosystems.

Based on our study's results, we suggest that, to ensure the sustainable management of Europe's rivers, certain countries should implement financial mechanisms that allow local stakeholders (e.g., NGOs) to apply for external funds to pay for local river restoration initiatives. Such programs would broaden the involvement of local stakeholders and decentralize river restoration initiatives, thus enhancing local stakeholders' responsibility for their rivers. At the same time, countries should implement national programs to address river restoration on nationwide scales to provide frameworks for planned and structured catchment-scale actions. 
Finally, being aware of possible drawbacks of our study related to limited availability of data, we suggest to analyze status of and perspectives on river restoration in a global scale, on the basis of bigger set of technical and funding-related data on restoration projects. Structured revision or meta-analysis of available data from Europe, Asia, Africa, Australia and America would allow to look at river restoration across geographic and temporal scales, revealing the importance of healthy rivers and their services to societies beyond the aspects discussed in our paper.

Supplementary Materials: The following are available online at www.mdpi.com/2071-1050/10/1/129/s1, Table S1: Set of data on selected river restoration projects analyzed in the paper.

Acknowledgments: We sincerely thank all the experts from 19 European countries that participated in the survey. We also thank three anonymous reviewers for their thoughtful comments that allowed us to improve the manuscript.

Author Contributions: Ewelina Szałkiewicz collected and analyzed the data and wrote first draft of the paper. Szymon Jusik collected data and participated in interpretation of results and paper preparation. Mateusz Grygoruk analyzed the data and prepared final draft of the paper.

Conflicts of Interest: The authors declare no conflict of interest.

\section{References}

1. Suding, K.N. Toward an era of restoration in ecology: Successes, failures and opportunities ahead. Ann. Rev. Ecol. Evol. Syst. 2011, 42, 456-487. [CrossRef]

2. Martinez, M.L.; Lopez-Barrera, F. Special issue: Restoring and designing ecosystems for a crowded planet. Ecoscience 2008, 15, 1-5. [CrossRef]

3. Hobbs, R.H.; Harris, J.A. Restoration ecology: Repairing the Earth's ecosystems in the new millennium. Restor. Ecol. 2001, 9, 239-246. [CrossRef]

4. Choi, Y.D.; Temperton, E.B.; Allen, A.P.; Grootjans, M.; Halassy, M.; Hobbs, M.A.; Naeth, M.K.; Torok, K. Ecological restoration for future sustainability in a changing environment. Ecoscience 2008, 15, 53-64. [CrossRef]

5. Nielsen-Pincus, M.; Moseley, C. The economic and employment impacts of forest and watershed restoration. Restor. Ecol. 2013, 21, 207-214. [CrossRef]

6. Aronoson, J.; Blingnaut, J.N.; Milton, S.J.; Le Maitre, D.; Esler, K.J;; Limouzin, A.; Fontaine, C.; De Wit, M.P.; Mugido, W.; Prinsloo, P.; et al. Are Socioeconomic Benefits of Restoration Adequately Quantified? A Meta-analysis of Recent Papers (2000-2008) in Restoration Ecology and 12 other Scientific Journals. Restor. Ecol. 2010, 18, 143-154. [CrossRef]

7. BenDor, T.; Lester, W.T.; Livengood, A.; Davis, A.; Yonavjak, L. Estimating the size and impact of the ecological restoration economy. PLoS ONE 2015. [CrossRef] [PubMed]

8. Ehrenfeld, J.G. Defining the Limits of Restoration: The Need for Realistic Goals. Restor. Ecol. 2000, 8, 2-9. [CrossRef]

9. Jähnig, S.C.; Lorenz, A.W.; Hering, D.; Antons, C.; Sundermann, A.; Jedicke, E.; Haase, P. River restoration success: A question of perception. Ecol. Appl. 2011, 21, 2007-2015. [CrossRef] [PubMed]

10. Petursdottir, T.; Aradottir, A.; Benediktsson, K. An Evaluation of the Short-Term Progress of Restoration Combining Ecological Assessment and Public Perception. Restor. Ecol. 2013, 21, 75-85. [CrossRef]

11. Lave, R.; Doyle, M.; Robertson, M. Privatizing stream restoration in the US. Soc. Stud. Sci. 2010, 40, 677-703. [CrossRef]

12. Grygoruk, M.; Acreman, M. Restoration and management of riparian and riverine ecosystems: Ecohydrological tools, experiences and perspectives. Ecohydrol. Hydrobiol. 2015, 15, 109-110. [CrossRef]

13. Dynesius, M.; Nilsson, C. Fragmentation and flow regulation of river systems in the Northern third of the World. Science 1994, 266, 753-762. [CrossRef] [PubMed]

14. Palmer, M.A.; Hondula, K.L.; Koch, B.J. Ecological restoration of streams and rivers: Shifting strategies and shifting goals. Ann. Rev. Ecol. Evol. Syst. 2014, 45, 247-269. [CrossRef]

15. Palmer, M.A.; Bernhardt, E.S.; Allan, J.D.; Lake, P.S.; Alexander, G.; Brooks, S.; Carr, J.; Clayton, S.; Dahm, C.N.; Follstad Shah, J.; et al. Standards for ecologically successful river restoration. J. Appl. Ecol. 2005, 42, 208-217. [CrossRef] 
16. Costanza, R.; d'Arge, R.; de Groot, R.; Farber, S.; Grasso, M.; Hannon, B.; Limburg, K.; Naeem, S.; Oneill, R.V.; Paruelo, J.; et al. The value of the world's ecosystem services and natural capital. Nature 1997, 387, 253-260. [CrossRef]

17. Brandyk, A.; Majewski, G.; Kiczko, A.; Boczoń, A.; Wróbel, M.; Porretta-Tomaszewska, P. Ground Water Modelling for the Restoration of Carex Communities on a Sandy River Terrace. Sustainability 2016, 8, 1324. [CrossRef]

18. Cui, B.; Wang, C.; Tao, W.; You, Z. River channel network design for drought and flood control: A case study of Xiaoqinghe River basin, Jinan City, China. J. Environ. Manag. 2009, 90, 3675-3686. [CrossRef] [PubMed]

19. Erwin, K.L. Wetlands and global climate change: The role of wetland restoration in a changing world. Wetl. Ecol. Manag. 2009, 17, 71. [CrossRef]

20. Grygoruk, M.; Bańkowska, A.; Jabłońska, E.; Janauer, G.A.; Kubrak, J.; Mirosław-Świątek, D.; Kotowski, W. Assessing habitat exposure to eutrophication in restored wetlands: Model-supported ex-ante approach to rewetting drained mires. J. Environ. Manag. 2015, 152, 230-240. [CrossRef] [PubMed]

21. Grygoruk, M.; Mirosław-Świątek, D.; Chrzanowska, D.; Ignar, S. How much for water? Economic assessment and mapping of floodplain water storage as a catchment-scale ecosystem service of wetlands. Water 2013, 5, 1760-1779. [CrossRef]

22. Costanza, R.; de Groot, R.; Sutton, P.; van der Ploeg, S.; Andreson, S.J.; Kubiszewski, I.; Farber, S.; Turner, K.R. Changes in the global value of ecosystem services. Glob. Environ. Chang. 2014, 26, 152-158. [CrossRef]

23. European Parliament. Directive 2000/60/EC of the European Parliament and of the Council Establishing a Framework for the Community Action in the Field of Water Policy; European Parliament: Brussels, Belgium, 2000.

24. Januer, G.A.; Albrecht, J.; Stratmann, L. Synergies and Conflicts between Water Framework Directive and Natura 2000: Legal Requirements, Technical Guidance and Experiences from Practice. In Wetlands and Water Framework Directive: Protection, Management and Climate Change; Ignar, S., Grygoruk, M., Eds.; Geoplanet: Earth and Planetary Sciences 2015; Springer: Berlin/Heidelberg, Germany, 2015; ISBN 978-3-319-13764-3.

25. Ignar, S.; Grygoruk, M. Wetlands and Water Framework Directive: Protection, Management and Climate Change; Geoplanet: Earth and Planetary Sciences 2015; Springer: Berlin, Germany, 2015; ISBN 978-3-319-13764-3.

26. Zingraff-Hamed, A.; Greulich, S.; Pauleit, S.; Wantzen, K.M. Urban and rural river restoration in France: A typology. Restor. Ecol. 2017, 25, 994-1004. [CrossRef]

27. Morandi, B.; Kail, J.; Toedter, A.; Wolter, C.; Piegay, H. Diverse Approaches to Implement and Monitor River Restoration: A Comparative Perspective in France and Germany. Environ. Manag. 2017, 60, 931-946. [CrossRef] [PubMed]

28. Del Tanago, M.G.; de Jalon, D.G.; Roman, M. River Restoration in Spain: Theoretical and Practical Approach in the Context of the European Water Framework Directive. Environ. Manag. 2012, 50, 123-139. [CrossRef] [PubMed]

29. Repository of RiverWIKI Containing Selected River Restoration Projects. Available online: https:// restorerivers.eu (accessed on 14 October 2016).

30. River Restoration in France. Available online: http://www.river-restoration.onema.fr/ (accessed on 14 October 2016).

31. Repository of River Restoration Projects Implemented in the UK. Available online: http:/ / www.therrc.co.uk (accessed on 20 November 2017).

32. Wohl, E.; Angermeier, P.L.; Bledsoe, B.; Kondlof, G.M.; MacDonnel, L.; Merritt, D.M.; Palmer, M.A.; LeRoy Poff, N.; Tarboton, D. River restoration. Water Resour. Res. 2005, 41, W10301. [CrossRef]

33. Bernhardt, E.S.; Palmer, M.A. River restoration-The fuzzy logic of repairing reaches to reverse watershed scale degradation. Ecol. Appl. 2011, 21, 1926-1931. [CrossRef] [PubMed]

34. Mioduszewski, W.; Okruszko, T. Protection of natural wetlands-Examples of conflicts. J. Water Land Dev. 2012, 16, 35-42. [CrossRef]

35. Grygoruk, M.; Rannow, S. Mind the Gap! Challenges for a science-based stakeholder dialogue in climate-adapted management of wetlands. J. Environ. Manag. 2017, 186, 108-119. [CrossRef] [PubMed]

36. Muro, M.; Hartje, V.; Klaphake, A.; Scheumann, W. Pilot Study in Identifying and Analysing Stakeholders for the Information and Consultation According to Art. 14 of the EU Water Framework Directive in a River Basin; Umweltbundesamt Texte 27-06; Umweltbundesamt: Dessau, Germany, 2007. 
37. Carter, T.R.; Jones, R.N.; Lu, X.; Bhadwal, S.; Conde, C.; Mearns, L.O.; O’Neill, B.C.; Rounsevell, M.D.A.; Zurek, M.B. New assessment methods and the characterisation of future conditions. In Climate Change 2007: Impacts, Adaptation and Vulnerability. Contribution of Working Group II to the Fourth Assessment Report of the Intergovernmental Panel on Climate Change; Parry, M.L., Canziani, O.F., Palutikof, J.P., van der Linden, P.J., Hanson, C.E., Eds.; Cambridge University Press: Cambridge, UK, 2007; pp. 133-171.

38. Wendt, C. A Common Tax Base for Multinational Enterprises in the European Union; Springer: Berlin, Germany, 2009.

39. Decree of the Minister of Finances of the Republic of Poland-Rozporzadzenie Ministra Finansów of the Republic of Poland $z$ dn. 20.01.1995 w Sprawie Amortyzacji Środków Trwatych Oraz Wartości Niematerialnych i Prawnych, a Także Aktualizacji Wyceny Środków Trwatych. Dz. U. Nr. 7, Poz. 34; Ministra Finansów of the Republic of Poland: Warsaw, Poland, 1995.

40. De Groot, R.; Brander, L.; van der Ploeg, S.; Costanza, R.; Bernard, F.; Braat, L.; Christie, M.; Crossman, N.; Ghermandi, A.; Hein, L.; et al. Global estimates of the value of ecosystems and their services in monetary units. Ecosyst. Serv. 2012, 1, 50-61. [CrossRef]

41. Cowx, I.; Angelopoulos, N.; Noble, R.; Slawson, D.; Buijse, T.; Wolter, C. Measuring River Restoration Success. Deliverable D5.1 of the Reform Project. 2013. Available online: http:/ / www.reformrivers.eu/system/files / 5.1\%20Measuring\%20river\%20restoration\%20success.pdf (accessed on 30 December 2017).

42. Press Note of the Ministry of Ecology (Ministre de la Transition Écologique et Solidaire) of the Republic of France Dated on 14.11.2017. Available online: www.ern.org/wp-content/uploads/sites/52/2017/11/ 20171114_cp_ministere-selune_dam_removal.pdf (accessed on 20 November 2017).

43. Repository of Dam Removal Projects in European Union. Available online: http:/ / damremoval.eu/casestudies / (accessed on 20 November 2017).

44. O'Connor, J.E.; Duda, J.J.; Grant, G.E. 1000 dams down and counting. Science 2015, 348, 496-497. [CrossRef] [PubMed]

45. Marcinkowski, P.; Grygoruk, M. Long-Term Downstream Effects of a Dam on a Lowland River Flow Regime: Case Study of the upper Narew. Water 2017, 9, 783. [CrossRef]

46. Magilligan, F.J.; Nislow, K.H. Changes in hydrologic regime by dams. Geomorphology 2005, 71, 61-78. [CrossRef]

47. Cooper, A.R.; Infante, D.M.; Wehrly, K.E.; Wang, L.; Brenden, T.O. Identifying indicators and quantifying large-scale effects of dams on fishes. Ecol. Indic. 2016, 61, 646-657. [CrossRef]

48. Naiman, R.J.; Decamps, H. The ecology of interfaces: Riparian zones. Ann. Rev. Ecol. Evol. Syst. 1997, 28, 621-658. [CrossRef]

49. Muller, M.; Biswas, A.; Martin-Hurtado, R.; Tortajada, C. Built infrastructure is essential. Science 2015, 349, 585-586. [CrossRef] [PubMed]

50. Bernhardt, E.S.; Palmer, M.A.; Allan, J.D.; Alexander, G.; Barnas, K.; Brooks, S.; Carr, J.; Clayton, S.; Dahm, C.; Follstad-Shah, J.; et al. Synthesizing US river restoration efforts. Science 2005, 308, 636-637. [CrossRef] [PubMed]

51. Nakamura, K.; Tockner, K.; Amano, K. River and wetland restoration: Lessons from Japan. BioScience 2006, 56, 419-429. [CrossRef]

52. Krueger, A.B.; Grossman, G.M. Economic growth and the environment. Q. J. Econ. 1995, 110, 353-377.

53. De Bruynab, S.M.; van den Bergh, J.C.J.M.; Opschoorac, J.B. Economic growth and emissions: Reconsidering the empirical basis of environmental Kuznets curves. Ecol. Econ. 1998, 25, 161-175. [CrossRef]

(C) 2018 by the authors. Licensee MDPI, Basel, Switzerland. This article is an open access article distributed under the terms and conditions of the Creative Commons Attribution (CC BY) license (http://creativecommons.org/licenses/by/4.0/). 